Mirlan Muktarovich Dyldaev, Candidate of Geography, Dean of Faculty of ecology and managment of K. Karasaev Bishkek State University Bishkek, Kyrgyz Republic dyldaev@mail.ru

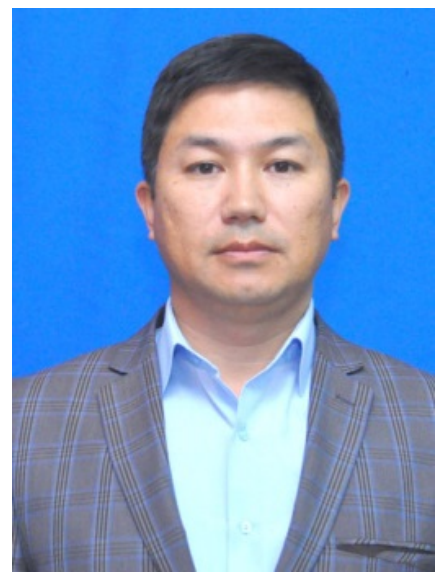

DOI 10.31554/978-5-7925-0571-1-2019-2-143-146

\title{
FEATURES OF URBANIZATION IN THE KYRGYZ REPUBLIC
}

In the Kyrgyz Republic, the urban population is $36 \%$. There are more than 31 cities in the country, and the main distinctive feature of urbanization is that it took place in a mountainous territorial location. Urban areas, as a rule, are mainly located in the valley and low-mountain zone of the Republic, with the exception of some urban systems, which are located in the mid-mountain part. In the Kyrgyz Republic natural and historical processes and cultural and traditional features have influenced the formation of a specific form of urbanization. It differs from the classical type in a relatively small historical period of time-about 100-150 years (excluding ancient fortresses, mausoleums and caravan trade sites). This distinguishes urbanization in the Republic from the world processes of urbanization, the continuity of which has a thousand-year history. In the last twenty years the pace of urbanization has become spontaneous, around large cities (Bishkek, Osh, etc.) so-called "new buildings" have grown, built up with low-rise buildings without adequate infrastructure, which has significantly worsened the sanitary-epidemiological and environmental situation.

Keywords: agglomeration, buffer zone, altitudinal zonality, geourbanistics, demographical process, migration, resettlement, urban areas.

The trend of urban population growth and urban sprawl has a dynamic of constant growth every year. This trend is increasingly observed in countries with transition economy. According to G. M. Lappo, one of the brightest representatives of geographical science and urbanism, the city is a special, 
incomparable creation of the human mind and hands. It is the living environment of an ever-increasing number of people and the place of concentration of various, increasingly diverse activities. The cities were named engines of progress. Something new is born there and spread from them. They are creative laboratoties, spiritual workshops of humanity. Classical geography of cities - as one of the most important scientific directions- originated in our country in the 30s [Lappo 1987, p. 46].

Another aspect of urbanization is the so-called "ecological shadow", i.e., the use of a large number of natural resources and raw materials to support the life of the city, which is also an increasing trend.

All this contributes to the emergence of a number of socio-economic problems associated with the processes of urban growth and population growth. Despite the fact that the process of urbanization itself which seems to be positive, according to many analysts, generates countless socioeconomic and environmental problems.

The main core of the modern structure and spatial development of urbanization in the Republic was the formation of urban areas in the context of large-scale industrialization and the transfer of defense enterprises. At the same time, the complexity of socio-economic transformations in the period of independence led to imbalances in the formation of urban settlements in the Republic as a whole and also to "false urbanization", which is particularly felt in the neighborhoods of large cities such as Bishkek and Osh.

In the Kyrgyz Republic a spesific mountain type of urbanization with its inherent elements is being formed.This type, which includes the features of classical", traditional" urbanization as well as forms of settlement, which are characteristic of mountain terrain or mountain type of urbanization, is referred to as "Mountain type of urbanization MU (Mountain Urbanization)".

By its nature, the urbanized territories of the Republic have a number of specific features typical for mountainous areas: a) urban settlements and overall settlements are formed in conditions of a mountain relief (the amplitude of the height above sea level is 450-7439 m), the most "upper" settlements and individual villages are located at an altitude of more than $3000 \mathrm{~m}$ above sea level; b) the majority of settlements are located in the valleyfoothill part and have the character of uneven placement (almost $80 \%$ of settlements are concentrated on $15 \%$ of the territory of the Republic). 
Thus, based on the works of geographers and urban planners K. Otorbaev (1988), S. D. Usenov (1991), E. K. Azykova (1988), M. M. Dyldaev (2015), there are three types of settlement in the Republic [Dyldaev 2018]:

I type - low-mountain settlement areas (1400 m above sea level);

II type - mid-mountain settlement areas (1400-1700 m above sea level);

III type - high-mountain settlement areas (more than $1700 \mathrm{~m}$ above sea level).

According to the altitude zone: $41 \%$ of urban areas are located up to 1000 m; 54\% of urban areas - from 1000 to 2000 m; one city Naryn (3 \%) above $2000 \mathrm{~m}$.

Defining the role of economic potential on the example of urbanization development in the Kyrgyz Republic, it should be noted that after the collapse of the planned economy in the early 1990s there were deep systemic transformations towards the disruption of the economic base. Of course, this could not but affect the development of urbanization processes in the country as a whole, which led to "uncontrolled chaotic urbanization", which is particularly felt in the development of not only large cities, but also medium and small urban entities in the Kyrgyz Republic. As a result, the flow of internal and external migration disrupted the demographic balance in the settlement system.

The economic transformations faced by the Kyrgyz Republic (the economic downturn, the decline in the social level of citizens) have affected the processes of urbanization and urban planning. Also, a weak city-forming base of cities, including industry, science, etc is also associated with the decline in the rate of urbanization. As a result of the decline in production many cities were in crisis in economic terms, the outflow of qualified personnel to other regions or countries of the near and far abroad increased. Therefore, urban settlements, budgets of local governments were not provided with funds allowing them to function and develop fully, including planning development prospects.

Due to the unsuitability and theft of social and cultural facilities many types of social and cultural services in settlements including small towns became inaccessible to most of the population during the period of independence. Problems with increasing morbidity, the provision of clean drinking water, etc appeared and worsened. In small towns of the Republic there is a real danger of outbreaks of certain infectious social diseases-tuberculosis, brucellosis, intestinal infections, pediculosis, etc. 
The geoecological state of cities in the Republic, depending on the degree of influence of various factors, has local tense manifestations. In many cities there is a real environmental threat, which requires the development of a strategy for environmentally sustainable development of the urban zone. Economic parameters, reasonable anthropogenic load on environment and health of the population should be system-forming factors of formation of ecological policy. At present, the formation of the natural and ecological framework of the urban environment mostly goes without taking into account the existing technogenic and natural processes, etc. The need for active inclusion of public-private partnership mechanisms in the environmental policy of the state seems justified,and the public - in decision-making on environmental issues.

Government support is needed in the development of the regions and the acceptance of the concept of resettlement as part of the ongoing administrativeterritorial reform, in providing comprehensive planning and promoting economic and social development of regions and districts, the formation of a uniform frame system of moving and placing settlements through the development of small and medium enterprises and service economy in cities. Also, it is necessary to introduce new industrial facilities in small cities every year with the involvement of investors at the state level.

\section{References and sources}

Dyldaev M. M., Sadykov S. I., Esenalieva B. B. Demograficheskiye protsessy v usloviyakh gornogo tipa pazmeshcheniya naselennykh punktov $\mathrm{v}$ Kyrgyzskoy Respublike [Demographic processes in the conditions of mountain type settlements in the Kyrgyz Republic]// Evraziyskoye nauchnoye obyedineniye [Eurasian scientific association]. - 2018. - № 5 (39). - P. 234-236.

Lappo G. M. Geografiya gorodov: ucheb.posobiye [Geography of cities: stud. textbook]/ G.M.Lappo. - M.: VLADOS, 1987. - 480 p. 